\title{
The Influence of Food Blogger to the Intention of Consuming Healthy Food
}

\author{
Theodosia C. Nathalia, Carla Kansius, Eunice Felicia, Ida Ayu Amanda Kalpikasari \\ Hospitality Management \\ Sekolah Tinggi Pariwisata Pelita Harapan \\ Tangerang, Indonesia \\ theodosia.nathalia@uph.edu
}

\begin{abstract}
The purpose of this study is to examine consumer behavior towards review and recommendation of food blogger regarding healthy eating lifestyle and to know whether there is a relation between food bloggers review and recommendation to healthy eating and consumer behavioral intention. The unit analysis in this research is people who know and read about food blog, with 192 valid questionnaires from respondents that reside in Jakarta, Bandung and Bogor. Data were analyzed using SPSS software.The result shows that all variables in the research have positive influence which means that perceived credibility and perceived usefulness of food blogger positively influences people's attitude towards healthy food which later influences their behavioral intention. The study found that food blogs have impact on encouraging people to eat healthy food, to raise awareness of the consumption of healthy food.
\end{abstract}

\section{Keywords - food blogger, healthy food eating}

\section{INTRODUCTION}

Over the past years, the consummation of healthy food becomes a trend and has been spreading to the society. This momentum started due to the increase awareness in eating healthy food habits in their daily life (Shaharudin et al., 2010) According to (W\&S Group, 2015) research about healthy food study in Thailand, Indonesia and Vietnam suggest that, 34.6\% of 500 respondents purchased healthy food more than once per week.

Finding the right media to influence healthy food consumption is important, according to (W\&S Group, 2015) advertising is the highest factor to influence the purchase of healthy food in Indonesia. Furthermore (Broadcasting Board of Governors \& GALLUP, 2012) research suggest that television is still the dominant form of media that is used, 95.5\% people use TV at least once a week to find news. (Waller and Lanasier, 2015) A study suggests that currently traditional media impacts public opinion the most. (Rani and Sharma, 2014) A study that analyzed various factors of consumer attitude towards television found that consumers consider that television advertising is an effective purchase decision medium. (East et al., 2008) A study about television advertisements, found that people strongly consider TV advertisement to impact their minds, influence purchasing decision and also can increase their frequency to purchase.

Indonesia's technology is also advancing. According to (W\&S Group, 2015), using Internet is the second highest form of source of information for healthy food after TV advertisement. Moreover, recent studies are against the theory, In traditional way according to (Mander, 2014) suggest, consumers make their purchase decisions mainly from information received through mass media (e.g. advertising, newspaper, television comment), but today, online social networks have power to influence consumers' purchase decision. According to a study (Yogesh and Yesha, 2014), social media does influence in purchasing decision. Now online media are ahead of traditional media in many markets (Mander, 2014). Time per-hour spent online is higher than hours spent using traditional media (Mander, 2014). Online media activities are dominantly use for social networking and micro- blogging (social media) taken $50 \%$ from all other activities (Mander, 2014). A research in Indonesia suggests that in 2012 about $22.2 \%$ of the population use social media with the highest percentage using Facebook and the highest use to search for the latest news (Broadcasting Board of Governors \& GALLUP, 2012).

The interest of healthy food in this digital technology era is then reflected in the social media, where it has been discovered that there is an increase post of food photography in regular basis in social media (Murphy, 2010). The advancement of technology in social media made blogs become a crucial way to spread writing about foods (Cox and Blake, 2010). According to a result of a research by (Hanifati, 2015) using technology acceptance model, food bloggers does influence consumer's behavioral intention. So does because user generated media like food blogger are more trusted than producer generated media to influence consumer's behavioral intention (Mir and Rehman, 2013.

This research aims to investigate whether food blogger can influence consumer to the intention to eat healthy food. Studies have investigate the influence of food blogger to consumers but have little of research on its influence to healthy food. The research is also conducted in hope to increase the awareness, promoting healthy food eating as well 
as to educate society of what healthy food is through food blogger.

\section{RESEARCH METHODS}

The sampling method used in this research is nonprobability-purposive sampling. Nonprobability sampling is a sampling design in which the elements in the population are not being predestined or not having probability to be chosen as sample subjects (Sekaran and Bougue, 2013). In nonprobability sampling design there is purposive sampling which is enclosed to specific people that can provide information that researchers go for. Nonprobability purposive sampling method is suitable for this research because not all people have the same chance to be the respondent and it is specified to only people who are familiar with food blogger.

As for the data collection, this research uses two types if data: primary data, which can be interpreted as information that was obtained first- hand by the researcher regarding variable of interest that is of use for the study (Sekaran and Bougue, 2013) and secondary data which refers to data is obtained from sources that has already exist, such as books and journals (Sekaran and Bougue, 2013). Example of primary data is questionaire which will be used as instrument to collect primary data in this research. The samples will be people who know and read about food blog and 200 questionnaires were distributed to respondents that reside in Jakarta, Bandung and Bogor. However, only 192 of them that were returned.

The variables used in this research would be perceived credibility, perceived usefulness, attitude towards using and behavioral intention, furthermore, to measure these variables, six-point Likert scale would be applied with $1=$ Strongly Disagree, 2 = Disagree, $3=$ Slightly Disagree, $4=$ Slightly Agree, $5=$ Agree, $6=$ Strongly Agree.

Furthermore, the methods of data analysis are descriptive analysis and quantitative analysis. Descriptive analysis is performed in order to find out general descriptive of respondent's response towards variable of Perceived Credibility, Perceived Usefulness, Attitude towards Using and Behavioral Intention. Respondent's statistic data includes relative frequency, mean, maximum, minimum, standard deviation and other indicator. Descriptive analysis for this research will be done with the help of SPSS software. On the other hand, quantitative data analysis would include the relation between variables, perceived credibility and perceived usefulness to attitude towards using, and the relation between attitudes towards using to behavioral intentions. In this analysis, it would include several tests such as reliability and validity test, regression analysis, correlation analysis, coefficient of determination, analysis of variance and t-test.

\section{RESULT AND DISCUSSION}

In order to solve the problem of this research, descriptive analysis and quantitative analysis were used as the data analysis method, from the descriptive analysis, it could describe respondent's profile, their gender, age, the frequency of eating healthy food, their experience in reading food blogs, experience in following food blogger's recommendation, the amount of times in following food bloggers recommendation, the media used to read food blog and questions regarding the perceived credibility, perceived usefulness, the attitude towards using and the behavior intention of the respondent towards food blogger to the intention of eating healthy food. From the descriptive statistics, it was found out that majority of the respondents were female $(58.9 \%)$ and the rest were male with $41.1 \%$. The data also appeared to be dominated with age range of $\leq 25$ years old, which suggests that most of the people who are well aware of food bloggers are people below and at the age of 25.

Furthermore, the frequency of people consuming healthy food in a month suggest that (30.7\%) eats 3-6 times, which is the highest number following, people eating 10 times or more $(28.6 \%), 1-3$ times $(26,6 \%)$ and 6-9 times $(14.1 \%)$. It can be concluded that Indonesia have started to implement eating healthy food in their lifestyle from the number of time they eat healthy food in a month. Through the response of indicators from each variables, it was known that the society have positive response in following food bloggers recommendation to consume healthy food or at least considering to consume healthy food through food blogger's recommendation.

Moving forwards to quantitative analysis method, there is reliability and validity test to measure how reliable the instruments used and how well the instruments are measuring the concept they were intended to measure. Below is the table of reliability test that was obtained from SPSS calculation:

TABLE I. RELIABILITY STATISTICS

\begin{tabular}{|c|c|}
\hline Cronbach's Alpha & $\mathrm{N}$ of Item \\
\hline ,930 & \\
\hline
\end{tabular}

From the table, the Cronbach's Alpha was known to be 0,930 with number of items 17 , and it can be considered that the data used is good [10]. For the hypothesis testing, $f$ test and test were conducted as well, and from both test it could be concluded that null hypotheses $\left(\mathrm{H}_{0}\right)$ was rejected and alternative hypotheses were accepted $\left(\mathrm{H}_{1}, \mathrm{H}_{2}, \mathrm{H}_{3}\right)$. It was due to the value of $|t|$ and $F_{\text {calculation that }}$ are bigger than $t_{\text {table and }}$ $\mathrm{F}_{\text {table. }}$

\section{CONCLUSION}

The result of research "The Influence of Food Blogger to the Intention of Consuming Healthy Food Questionnaire" supports the theory model that is proposed. From the result it was known that all variables have positive influence which means that perceived credibility and perceived usefulness of food blogger positively influences people's attitude towards healthy food which later influences their behavioral intention. Therefore, food bloggers played quite important role in affecting people's behavioral intention and people's attitude towards recommendation of food blogger was 
showned to be positive. According to the result, it is safe to say that promoting or introducing healthy food to the society can be done through the help of food blogger, so long as they have the perceived credibility and usefulness adhered to them.

\section{REFERENCE}

Broadcasting Board of Governors, and GALLUP. (2012). Media Use in 2012, Retrieved May 20, 2016, from http://www.bbg.gov/wp- content/media/2012/10/gallupindonesia-brief.pdf

Cox, A, and Blake, M. (2011). Information and food blogging as serious leisure (Vol. 63), Adlib Proceedings.http://dx.doi.org/10.1108/000125311111356 64

East, R, Wright, M, and Vanhuele, M. (2008). Consumer behaviour: Applications in marketing. Los Angeles: Sage Publications.

Hanifati, A. (2015). The Impact of Food Blogger toward Consumer's Attitude and Behavior in Choosing Restaurant, 3(3).

Mander, J. (2014). Digital vs Traditional Media Consumption [PDF], Global Web Index.

Mir, I. A, and Rehman, K. U. (2013). FACTORS AFFECTING CONSUMER ATTITUDES AND INTENTIONS TOWARD USER-GENERATED
PRODUCT CONTENT ON YOUTUBE, 8.

Murphy, K. (2010). First camera, then fork. The New York Times. $\quad$ Retrieved May 20, 2016, from http://www.nytimes.com/2010/04/07/dining/07camera.ht $\mathrm{ml}$ ?page wanted=all\&_r0.

Rani, N, and Sharma, V, Dry. (2014, January). Impact of Television Commercials on Purchasing Behavior of Masses, $\quad 5(1)$. $\quad$ Retrieved from https://www.ijsr.net/archive/v5i1/NOV153070.pdf

Saharan, U.S, Bougie, R. and IVONNE, P. (2013). Research methods for business: A skill-building approach. (6th edn), Hoboken, NJ, United States: John Wiley \& Sons.

Shaharudin, M. R, Pani, J. J, Mansor, S. W., Elias, S. J., and Sadek, D. M. (2010, May). Purchase Intention of Organic Food in Kedah, Malaysia; A Religious Overview, 2.

W\&S Group. (2015, May). Comparative Report on Healthy Food in Thailand, Indonesia and Vietnam in 2015 [PPT].

Waller, D. S., \& Lanasier, E. V. (2015, March 9).Attitudes of Indonesian Mothers Toward Food Advertising Directed to Children.

Yogesh, F., \& Yesha, M. (2014, May). Effect of Social Media on Purchasing Decision, 6(11). Retrieved from http://www.pbr.co.in/May2014/9.pdf 